\title{
Comparison of Maximal Oxygen Consumption between Obese Black and White Adolescents
}

\author{
JOSEPH L ANDREACCI, ROBERT J ROBERTSON, JOHN J DUBÉ, DEBORAH J AARON, \\ CURT B DIXON, AND SILVA A ARSLANIAN,
}

\author{
Department of Exercise Science, Bloomsburg University, Bloomsburg, PA, 17815 [J.L.A]; Center for \\ Exercise and Health-Fitness Research, School of Health, Physical and Recreation Education, University of \\ Pittsburgh, Pittsburgh, PA, 16261 [R.J.R., J.J.D., D.J.A.]; Department of Health Sciences, Lock Haven \\ University, Lock Haven, PA, 17745 [C.B.D.]; Division of Pediatric Endocrinology Children's Hospital, \\ University of Pittsburgh, Pittsburgh, PA, 15260 [S.A.A.]
}

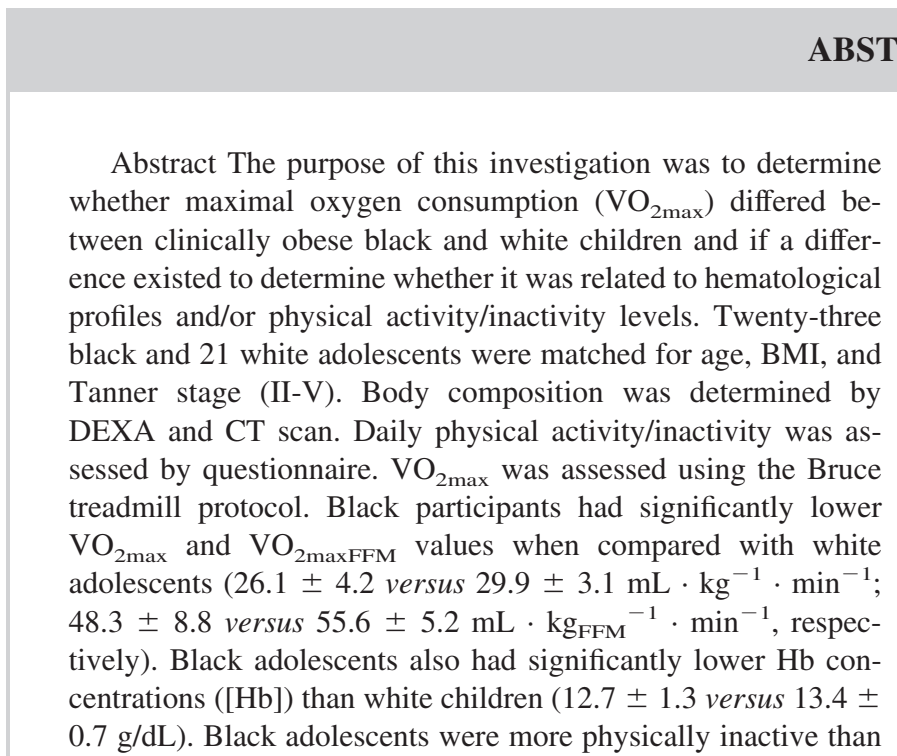

their white peers. $\mathrm{VO}_{2 \max }$ correlated with $[\mathrm{Hb}]$ for the combined groups. Obese black adolescents had lower $\mathrm{VO}_{2 \max }$ compared with white children and this difference was explained, in part, by the lower $[\mathrm{Hb}]$ observed in the black participants. Further investigations should study $\mathrm{Hb}$ flow rate (a function of $[\mathrm{Hb}] \cdot$ maximal cardiac output) and physical activity/inactivity patterns in obese black and white children as it relates to $\mathrm{VO}_{2 \max }$ (Pediatr Res 58: 478-482, 2005)

Abbreviations
BMI, body mass index,
VO,
[Hb], hemoglobin concentration,
HR, heart rate,
RER, respiratory exchange ratio,

Numerous investigations have demonstrated that there is a difference in $\mathrm{VO}_{2 \max }$ between black children compared with white children $(1-8)$. We recently reported that $\mathrm{VO}_{2 \max }$ was significantly lower in nonobese black prepubertal and pubertal children when compared with white children matched for age pubertal stage and BMI (8). Several factors have been associated with the differences in $\mathrm{VO}_{2 \max }$ between black and white youth these include hematological profiles $(4-6,8)$, physical activity levels $(5,7-10)$, and body composition $(1,6)$. In our previous investigation, we concluded that the comparatively lower $\mathrm{VO}_{2 \max }$ in black children was partly attributed to a lower $\mathrm{Hb}$ concentration $([\mathrm{Hb}])$ and higher physical inactivity levels

Received November 1, 2004; Accepted January 3, 2005.

Correspondence:: Joseph L. Andreacci, Ph.D., 130 Centennial Hall, Bloomsburg University, 400 East Second Street, Bloomsburg, PA 17815, U.S.A. Office: (570) 389-5340, Fax: (570) 389-5047; email: jandreac@bloomu.edu

This investigation was supported by United States Public Health Service grant RO1 HD27503 (S.A.A.), K24 HD01357 (S.A.A.), MO1 RR00084 General Clinical Research Center, Renziehausen Trust Fund, and Eli Lilly and Company (S.A.A.).

DOI: 10.1203/01.pdr.0000176909.66057.a3
(8). While evidence is extremely limited, differences in [Hb] and associated $\mathrm{VO}_{2 \max }$ values between blacks and whites have been observed in both healthy children and adults. To our knowledge, no investigations have examined the effect of [Hb] on $\mathrm{VO}_{2 \max }$ in young obese black and white adolescents.

Obesity has been associated with significant health problems in the pediatric age group and is an important risk factor for adult morbidity and mortality (11-13). Obesity in children and adolescents is widely recognized as a contributing factor to various conditions such as: impaired glucose tolerance; type 2 diabetes; hyperlipidemia; hypertension and reduced cardiorespiratory/aerobic fitness (14-17). In addition, comparatively lower levels of cardiovascular/aerobic fitness may interact with one or more of these clinical states, further exacerbating their clinical sequelae.

Therefore, the purpose of this follow on investigation was to determine whether $\mathrm{VO}_{2 \max }$ differed between clinically obese black and white children and whether a difference existed to determine whether it was related to hematological profiles and/or physical activity/inactivity levels. 


\section{METHODS}

Participants. Twenty-three clinically obese $\left[\mathrm{BMI} \geq\right.$ the $95^{\text {th }}$ percentile for age and sex] black and 21 white adolescents aged 10.9 to 16.8 y participated in this study. Pubertal development was assessed by physical examination according to the criteria of Tanner (18). All study participants were determined to be in Tanner stages $\geq$ II-V of development. Some of the subjects had participated in an investigation reported previously (19). All subjects were in good health based on clinical history, physical examination and hematological profiles. All subjects had normal glycosylated $\mathrm{Hb}$ values. No subjects were receiving medications and none were competitive athletes. Table 1 lists the clinical characteristics of the study participants.

Study participants were recruited through newspaper advertisements in the community. All studies were approved by the Human Rights Committee of Children's Hospital of Pittsburgh. Research participants and parents/guardians gave written informed assent and consent after receiving a thorough explanation of the research project. All children were studied in the General Clinical Research Center at Children's Hospital of Pittsburgh and at the Center for Exercise and Health-Fitness Research at the University of Pittsburgh.

Experimental design. All subjects were admitted to the General Clinical Research Center in the early afternoon before testing. Participants were advised to follow a weight maintenance diet containing 55\% carbohydrate, $30 \%$ fat, and $15 \%$ protein for $1 \mathrm{wk}$ before testing. After admission to the General Clinical Research Center subjects were transported to the Center for Exercise and Health-Fitness Research at the University of Pittsburgh where a physical activity questionnaire and $\mathrm{VO}_{2 \max }$ test were administered.

Biochemical measurement. Blood samples were obtained, from the anticubital vein after a 12 -h overnight fast. Uncoagulated whole blood was immediately analyzed to obtain values for $[\mathrm{Hb}]$. $\mathrm{Hb}$ was determined by the cyanide method using a Coulter Gen-S System (Beckman Coulter Inc.Atlanta, GA).

Body composition and abdominal adiposity. Body composition was assessed by dual-energy x-ray absorptiometry. S.c adipose tissue was assessed by a 10-mm single axial computed tomography scan of the abdomen at the leve of $\mathrm{L}_{4-5}$ lumbar vertebra as described by us previously (20). The volume of visceral adipose tissue was electronically calculated (21).

Physical activity assessment. Physical activity was assessed by the Modifiable Activity Questionnaire (MAQ) that separately measured physical, leisure-time activity and inactivity $(22,23)$. Vigorous activity and physical inactivity were assessed exactly as described previously.8 Leisure-time activity was assessed by asking the subject to recall activities that they participated in at least 10 times over the past year $(22,23)$.

Maximal oxygen consumption. Maximal oxygen consumption $\left(\mathrm{VO}_{2 \max }\right)$ was indexed to total body mass $\left(\right.$ i.e., $\left.\mathrm{mL} \cdot \mathrm{kg}^{-1} \cdot \mathrm{min}^{-1}\right)$ and fat free mass $(i . e$., $\mathrm{mL} \cdot \mathrm{kg}_{\mathrm{FFM}}{ }^{-1} \cdot \min ^{-1}$ ) and measured using the Bruce multistage treadmill protocol. This protocol is suitable for use with children ages $4 \mathrm{y}$ and older $(8,24)$. All tests were conducted on a Quinton (model Q-65) motor-driven treadmill. The attainment of $\mathrm{VO}_{2 \max }$ was accepted when the participants demonstrated any two of the following three criteria: 1) a change in $\dot{\mathrm{V}}_{2}$ of $<$ $2.1 \mathrm{~mL} \cdot \mathrm{kg}^{-1} \cdot \mathrm{min}^{-1}$ with increasing exercise intensity at near-maximum higher treadmill stages, 2) a respiratory exchange ratio (RER) of $\geq 1.05$, and 3 ) heart rate (HR) $>90 \%$ of the age-predicted maximum at the end of the exercise test $(6-8)$. HR was measured continuously throughout the exercise test using a Polar Monitor System (Polar Electro, Inc., Woodbury, NY). Expired gases were collected and analyzed by open circuit spirometry in 15-s

Table 1. Participant characteristics

\begin{tabular}{lcc}
\hline & Black & White \\
\hline $\mathrm{N}$ & 23 & 21 \\
Sex $(\mathrm{M} / \mathrm{F})$ & $14 / 9$ & $11 / 10$ \\
Age $(\mathrm{yrs})$ & $13.3 \pm 1.7$ & $13.2 \pm 1.6$ \\
Height $(\mathrm{cm})$ & $161.2 \pm 7.4$ & $162.0 \pm 9.8$ \\
Weight $(\mathrm{kg})$ & $91.2 \pm 18.3$ & $87.2 \pm 19.0$ \\
BMI $\left(\mathrm{kg} / \mathrm{m}^{2}\right)$ & $34.9 \pm 5.6$ & $32.9 \pm 4.8$ \\
FM $(\mathrm{kg})$ & $37.8 \pm 8.7$ & $34.4 \pm 9.4$ \\
FFM $(\mathrm{kg})$ & $47.1 \pm 7.9$ & $45.6 \pm 10.2$ \\
BF $(\%)$ & $42.9 \pm 4.1$ & $41.7 \pm 6.0$ \\
VAT $\left(\mathrm{cm}^{2}\right)$ & $63.2 \pm 26.8$ & $81.2 \pm 27.6$ \\
SAT $\left(\mathrm{cm}^{2}\right)$ & $518.1 \pm 167.9$ & $502.5 \pm 142.3$ \\
{$[\mathrm{Hb}](\mathrm{g} / \mathrm{dL})$} & $12.7 \pm 1.3^{*}$ & $13.4 \pm 0.7$ \\
\hline
\end{tabular}

All values are mean \pm SD. FM, fat mass; $B F$, body fat; VAT, visceral adipose tissue; SAT, subcutaneous adipose tissue.

$* p<.05$. intervals using a Parvo Medics TrueMax 2400 metabolic measurement system (Salt Lake City, UT). The analyzer was calibrated with gases of known concentrations before each testing session according to the manufacture's guidelines. Verbal encouragement was given to all subjects to elicit a maximal effort.

Statistical analysis. All statistical analyses were performed using SPSS-PC (version 11.0; SPSS Inc, Chicago) and SAS (version 8.0; SAS Institute Inc., Cary, NC). Comparison of physiologic, hematological and body composition variables between black and white children were made with using an unpaired two-tailed $t$ test. A $\chi^{2}$ analysis was used to determine whether differences existed in the various physical activity measures between the subject groups. Because of multiple comparisons, $t$ values were expressed using a BonferroniDunn inequality adjustment. All data are presented as a mean \pm SD. Pearson correlation coefficients were calculated to identify relations between selected variables. Multiple regression analysis was applied to evaluate multivariate relations.

\section{RESULTS}

Characteristics for the initial pool of study participants are presented in Table 1 . Three subjects ( 1 black and 2 white) failed to meet the criteria for $\mathrm{VO}_{2 \max }$ and were excluded from further data analysis.

Obese black adolescents had significantly lower $\mathrm{VO}_{2 \max }$ and $\mathrm{VO}_{2 \operatorname{maxFFM}}$ values when compared with the white adolescents $\left(26.1 \pm 4.2\right.$ versus $29.9 \pm 3.1 \mathrm{~mL} \cdot \mathrm{kg}^{-1} \cdot \min ^{-1}, p<0.05$; $48.3 \pm 8.8$ versus $55.6 \pm 5.2 \mathrm{~mL} \cdot \mathrm{kg}_{\mathrm{FFM}}{ }^{-1} \cdot \min ^{-1}, p<0.05$, respectively; Table 2). No differences were observed between racial groups with respect to maximal HR or maximal respiratory exchange ratio (Table 2). Obese black adolescents had significantly lower $[\mathrm{Hb}]$ when compared with their white peers $(12.7 \pm 1.3$ versus $13.4 \pm 0.7 \mathrm{~g} / \mathrm{dL}, p<0.05$; Table 1$)$.

$\chi^{2}$ analysis indicated $(p<0.05)$ that obese black adolescents were more physically inactive than their white peers (Table 3 ). No between group differences were observed for measures of vigorous physical activity and leisure-time physical activity (Table 3).

For the total subject sample, $\mathrm{VO}_{2 \max }$ correlated with $[\mathrm{Hb}$, sex and race $(r=0.379, p<0.01: r=-.350, p<0.05$; and $r=-.319, p<0.05$, respectively). No significant correlations were observed between any measure of physical activity and $\mathrm{VO}_{2 \max }$. Stepwise multiple-regression analysis was used to determine the relative contributions of race, $[\mathrm{Hb}]$ and sex in explaining the variance in $\mathrm{VO}_{2 \max }$ (Table 4, model 1). Both race $(p<0.05)$ and sex $(p<0.05)$ entered the model as significant predictors, combining to explain $28 \%$ of the variance in $\mathrm{VO}_{2 \max }$. A second stepwise multiple-regression analysis was used to determine the relative contributions of race, physical inactivity and sex in explaining the variance in $\mathrm{VO}_{2 \max }$ (Table 4, model 2). Both race $(p<0.05)$ and sex $(p<$ 0.01 ) entered the model as significant predictors, combining to explain $25 \%$ of the variance in $\mathrm{VO}_{2 \max }$ (Table 4 , model 2 ).

Table 2. Maximal exercise responses

\begin{tabular}{lcc}
\hline & $\begin{array}{c}\text { Black } \\
(\mathrm{n}=22)\end{array}$ & $\begin{array}{c}\text { White } \\
(\mathrm{n}=19)\end{array}$ \\
\hline $\mathrm{RER}$ & $1.05 \pm 0.08$ & $1.08 \pm 0.08$ \\
$\mathrm{HR}$ (beats $/ \mathrm{min})$ & $189 \pm 9$ & $193 \pm 6$ \\
$\mathrm{VO}_{2 \max }\left(\mathrm{mL} \cdot \mathrm{kg}^{-1} \cdot \mathrm{min}^{-1}\right)$ & $26.1 \pm 4.2^{*}$ & $29.9 \pm 3.1$ \\
$\mathrm{VO}_{2 \mathrm{FFM}}\left(\mathrm{mL} \cdot \mathrm{kg}_{\mathrm{FFM}}{ }^{-1} \cdot \mathrm{min}^{-1}\right)$ & $48.3 \pm 8.8^{*}$ & $55.6 \pm 5.2$ \\
\hline
\end{tabular}

All values are mean SD. RER, respiratory exchange ratio; HR, heart rate; $\mathrm{VO}_{2 \mathrm{FFM}}$, oxygen consumption per fat free mass.

$* p<.05$. 
Table 3. Physical activity questionnaire assessment

\begin{tabular}{lcr}
\hline & $\begin{array}{c}\text { Black } \\
(\mathrm{n}=22)\end{array}$ & $\begin{array}{c}\text { White } \\
(\mathrm{n}=19)\end{array}$ \\
\hline Vigorous physical activity & & \\
$\quad$ None & $7(31.8 \%)$ & $8(42.1 \%)$ \\
$\quad \geq 1$ day & $15(68.2 \%)$ & $11(57.9 \%)$ \\
Physical inactivity & & \\
$\quad<4$ hrs/day & $5(22.7 \%)$ & $10(52.6 \%)$ \\
$\quad \leq 4$ hrs/day & $17(77.3 \%) *$ & $9(47.4 \%)$ \\
Leisure-time physical activity (hrs/wk) & $9.1 \pm 5.5$ & $11.5 \pm 8.7$ \\
\hline
\end{tabular}

Number of participants (percentage within group), means \pm SD. Vigorous physical activity was defined as the number of days in the past 14 spent doing 20 minutes of hard exercise. Physical inactivity was defined as the number of hours per day spent watching television and video's, or playing on the computer or video games.

$* p<.05$.

\section{DISCUSSION}

The primary finding of this investigation was that clinically obese black adolescents had significantly lower $\mathrm{VO}_{2 \max }$ levels when compared with white children matched for age, pubertal stage and BMI. The attainment of $\mathrm{VO}_{2 \max }$ was confirmed for both racial groups of adolescents using HR and RER criteria. The similarities of maximal HR and RER between the two racial groups were consistent with previous investigations (6$8,25)$.

Maximal oxygen uptake. The main conclusion from this investigation was that $\mathrm{VO}_{2 \max }$ was $13 \%$ lower in obese black children when compared with their white peers. The difference in $\mathrm{VO}_{2 \max }$ between black and white children was still present when $\mathrm{VO}_{2 \max }$ was indexed to FFM $\left(\mathrm{mL} \cdot \mathrm{kg}_{\mathrm{FFM}}{ }^{-1} \cdot \mathrm{min}^{-1}\right)$. Our findings are consistent with the previously reported $12 \%$ to $20 \%$ lower $\mathrm{VO}_{2 \max }$ values in black compared with white children (1-8). Gutin et al. (7) reported that obese black boys and girls (ages 13-16 y) had significantly lower $\mathrm{VO}_{2 \max }$ values when compared with white adolescents of the same age and body composition. However, our study is the first investigation that carefully matched racial groups of obese children with respect to age, pubertal stage, BMI and body composition. The $\mathrm{VO}_{2 \max }$ values reported presently for both of the black and white obese children are generally consistent with these previously established ranges.

Hematological profiles. Our finding that $[\mathrm{Hb}]$ was lower in black adolescents when compared with white is consistent with previous investigations $(6,8,26,27)$. Garn et al. (26) reported that black children had an average $[\mathrm{Hb}] \sim 1 \mathrm{~g} / \mathrm{dL}$ lower than white children. Dallman et al. (27) also found that black children had significantly lower $\mathrm{Hb}$ values, by $\sim 0.5 \mathrm{~g} / \mathrm{dL}$, when compared with white and Asian children of the same sex and age.
One factor that may explain the race differences in $\mathrm{VO}_{2 \max }$ observed presently is that black children had significantly lower $[\mathrm{Hb}]$ when compared with their white peers. This comparatively lower hematological profile, while still within the clinically normal range, may have decreased central circulatory oxygen transport capacity producing a corresponding decrease in total body oxygen consumption at maximal exercise intensities (28). Rowland noted that relatively small changes in $[\mathrm{Hb}]$ or total circulating $\mathrm{Hb}$ mass have a profound effect on $\mathrm{VO}_{2 \max }$ in both adolescent boys and girls (29). The present data are consistent with previously reported differences in hematological profiles between black and white individuals of normal body weight $(5-8,30)$. Pivarnik et al. (6) found that a selected group of black girls (mean age $=13.5 \mathrm{y}$ ) had venous $[\mathrm{Hb}]$ levels that were significantly lower than those of white girls and these differences in hematological profiles were associated with corresponding differences in $\mathrm{VO}_{2 \max }$. In addition, we previously reported that significantly lower $[\mathrm{Hb}]$ was associated with a lower $\mathrm{VO}_{2 \max }$ in normal weight black prepubertal and pubertal children when compared with white children.8 The current investigation is, to our knowledge, among the first to observe an association between the lower $[\mathrm{Hb}]$ and $\mathrm{VO}_{2 \max }$ in obese black and white adolescents.

The average $[\mathrm{Hb}]$ values for both racial groups used presently fell within clinically accepted normal limits. Nevertheless, it is possible that the lower values in the obese black participants resulted in lower oxygen transport to peripheral tissues and subsequently less oxygen extraction by exercising skeletal muscle during the treadmill test. The significant $(p<$ 0.01 ) positive correlation between $[\mathrm{Hb}]$ and $\mathrm{VO}_{2 \max }$ is consistent with this proposed mechanism. At maximal exercise intensities oxygen transport is a function of $\mathrm{Hb}$ flow rate [i.e., $[\mathrm{Hb}]$ maximal cardiac output (31)]. Therefore, differences in $\mathrm{Hb}$ - flow rate can cause differences in $\mathrm{VO}_{2 \max }$. Assuming normal binding of oxygen with $\mathrm{Hb}$, we propose that a lower $\mathrm{Hb}$ flow rate and associated oxygen transport in part accounted for the lower $\mathrm{VO}_{2 \max }$ in the black participants.

Other possible mechanisms contributing to differences in $[\mathrm{Hb}]$ between black and white children could be genetic factors, such as sickle cell trait, dietary factors, such as iron deficiency, or some combination of these factors (27). It has been reported that $\sim 8$ to $10 \%$ of black individuals in the United Stated have sickle cell trait (32). Dietary iron deficiency is by far the most common cause of a subnormal $[\mathrm{Hb}]$ among ethnic groups (33).

Physical activity. Previous investigations have reported that aerobic fitness may be influenced by the level of physical activity and ethnicity $(4,34)$. Physical activity and inactivity have been shown to have a significant effect on aerobic fitness

Table 4. Multiple regression models

\begin{tabular}{|c|c|c|c|c|c|c|c|c|}
\hline \multirow[b]{3}{*}{ Outcome variable } & \multicolumn{4}{|c|}{ Model 1} & \multicolumn{4}{|c|}{ Model 2} \\
\hline & \multicolumn{4}{|c|}{$(\mathrm{n}=41)$} & \multicolumn{4}{|c|}{$(n=41)$} \\
\hline & $r^{2}$ & Race & {$[\mathrm{Hb}]$} & Sex & $r^{2}$ & Race & PinA & Sex \\
\hline $\mathrm{VO}_{2 \max }\left(\mathrm{mL} \cdot \mathrm{kg}^{-1} \cdot \min ^{-1}\right)$ & $.284 *$ & $-.296 *$ & .209 & $-.316^{* *}$ & $.359 *$ & $-.380 * *$ & -.060 & $-.381 *$ \\
\hline
\end{tabular}

PinA, physical inactivity. Independent variables are model 1, race sex; model 2, race PinA sex. Values for all independent variables are coefficients.

$* * p<0.05, * p<0.01$. 
in children $(7,35,36)$. Gutin et al. (7) reported that obese black children were significantly less vigorously active when compared with their white peers and that this was significantly correlated to cardiovascular fitness $(r=0.400, p<0.001)$. Although there are many social and behavioral factors that determine physical activity habits, some investigations have implicated ethnicity as a determinant of exercise patterns, with blacks and other ethnic minorities being less active than whites (36-38). Bouchard and Malina (39) have suggested that $\sim 60 \%$ of the variance in fitness is influenced by environmental and behavioral factors. Qualitative measures of physical inactivity (i.e., television viewing) have been positively associated with being overweight and obese in prepubertal children $(9,10)$

The black children in this study were more physically inactive when compared with their white peers. The data for these children are consistent with previous reports on minority adolescents $(9,10,40)$. Although no between group difference was observed in leisure time physical activity or vigorous physical activity, it was speculated that the greater amount of physical inactivity, observed in the black children could in part, have resulted in a lower $\mathrm{VO}_{2 \max }$. Based upon these findings it seems more likely that $\mathrm{VO}_{2 \max }$ was affected by both sedentary behaviors and hematological factors, rather than daily physical activity patterns. Further investigations are needed to more thoroughly evaluate the effect of daily physical activity patters on aerobic fitness in obese children.

Limitations of the current investigation include its restrictive sample, cross-sectional design and general reporting accuracy using the MAQ. However, these factors are assumed to have a limited impact on the conclusion reached. Because the investigation is cross-sectional in nature no causality can be determined. Further investigations should probe the relation between daily physical activity level and $\mathrm{VO}_{2 \max }$ in children of the age group studied.

Another possible factor, not examined in the present investigation that could have contributed to differences in $[\mathrm{Hb}]$ between black and white children could be differences in iron intake or in genetic traits. Both of these factors could have contributed to comparatively lower arterial $\mathrm{O}_{2}$ content and ultimately lower tissue respiration during maximal exercise in the black group. Future investigations should examine these potential mediating hematological factors more thoroughly.

\section{CONCLUSION}

It should be emphasized that the present findings demonstrated that $\mathrm{VO}_{2 \max }$ was lower in obese black than white adolescents and that these findings must be considered representative only of the specific group of children tested. The difference in maximal aerobic power may be, at least in part, attributed to the lower [Hb] and higher levels of physical inactivity in the black children. The observed difference in $\mathrm{VO}_{2 \max }$ between the racial groups was independent of body composition and daily physical activity level. Follow-up investigations should study $\mathrm{Hb}$ flow rate in black and white children as it relates to racial differences in $\mathrm{VO}_{2 \max }$. Also, further investigations should examine the possible role physical activ- ity/inactivity patterns have in obese black and white children as it relates to $\mathrm{VO}_{2 \max }$.

Acknowledgments. The authors thank Stephanie L. Albertson for her help in the preparation of this manuscript.

\section{REFERENCES}

1. Gutin B, Islam S, Manos T, Cucuzzo N, Smith C, Stachura ME 1994 Relation of percentage of body fat and maximal aerobic capacity to risk factors for atherosclerosis and diabetes in black and white seven-to eleven-year-old children. J Pediatr 125:847852

2. Arslanian S, Suprasongsin C, Janosky JE 1997 Insulin secretion and sensitivity in black versus white prepubertal healthy children. J Clin Endocrinal Metab 82:1923-1927

3. Ku CY, Gower BA, Hunter GR, Goran MI 2000 Racial differences in insulin secretion and sensitivity in prepubertal children: role of physical fitness and physical activity. Obes Res 8:506-515

4. Pivarnik JM, Fulton JE, Taylor WC, Snider SA 1993 Aerobic capacity in black adolescent girls. Res Q Exerc Sports 64:202-207

5. Trowbridge CA, Gower BA, Nagy TR, Hunter GR, Treuth MS, Goran MI 1997 Maximal aerobic capacity in African-American and Caucasian prepubertal children. Am J Physiol Endocrinol Metabol ;273:E809-E814

6. Pivarnik JM, Bray MS, Hergenroeder AC, Hill RB, Wong WW 1995 Ethnicity affects aerobic fitness in U.S. adolescent girls. Med Sci Sports Exerc 27:1635-1638

7. Gutin B, Barbeau P, Owens S, Lemmon CR, Bauman M, Allison J, Kang HS, Litaker MS 2002 Effects of exercise intensity on cardiovascular fitness, total body composition, and visceral adiposity of obese adolescents. Am J Clin Nutr 75:818-826

8. Andreacci JL, Robertson RJ, Dubé JJ, Aaron DJ, Balasekaran G, Arslanian SA 2004 Comparison of maximal oxygen consumption between black and white prepubertal and pubertal children. Pediatr Res 56: 706-713. Published online before print August 19, 2004 as DOI: 10.1203/01.PDR. 0000141521.77229.8D

9. Andersen RE, Crespo CJ, Bartlett SJ, Cheskin LF, Pratt M 1998 Relationship of physical activity and television watching with body weight and level of fatness among children: results from the Third National Health and Nutrition Examination Survey. JAMA 279:938-942

10. Gordon-Larsen P, McMurray RG, Popkin BM 2000 Determinants of adolescent physical activity and inactivity patterns. Pediatrics 105:E83-

11. Must A, Jacques PF, Dallal GE, Bajema CJ, Dietz WH 1992 Long-term morbidity and mortality of overweight adolescents. A follow-up of the Harvard Growth Study of 1922 to 1935 . N Engl J Med. 327:1350-1355.

12. Gunnell DJ, Frankel SJ, Nanchahal K, Peters TJ, Davey Smith G 1998 Childhood obesity and adult cardiovascular mortality: a 57-y follow-up study based on the Boyd Orr cohort. Am J Clin Nutr 67:1111-1118.

13. Eriksson JG, Forsén T, Tuomilehto J, Winter PD, Osmond C, Barker DJ 1999 Catch-up growth in childhood and death from coronary heart disease: longitudinal study. BMJ 318:427-431.

14. Pinhas-Hamiel O, Dolan LM, Daniels SR, Standiford D, Khoury PR, Zeitler P 1996 Increased incidence of non-insulin-dependent diabetes mellitus among adolescents. J Pediatr 128:608-615.

15. Sinha R, Fisch G, Teague B, Tamborlane WV, Banyas B, Allen K, Savoye M, Rieger V, Taksali S, Barbetta G, Sherwin RS, Caprio S 2002 Prevalence of impaired glucose tolerance among children and adolescents with marked obesity. N Engl J Med 346:802-810

16. Berenson GS, Srinivasan SR, Wattigney WA, Harsha DW 1993 Obesity and cardiovascular risk in children. Ann N Y Acad Sci 699:93-103

17. Freedman DS, Dietz WH, Srinivasan SR, Berenson GS 1999 The relation of overweight to cardiovascular risk factors among children and adolescents: the Bogalusa Heart Study. Pediatrics 103:1175-1182

18. Tanner JM 1981 Growth and maturation during adolescence. Nutr Rev 39:43-45

19. Bacha F, Saad R, Gungor N, Janosky J, Arslanian SA 2003 Obesity, regional fat distribution and syndrome $\mathrm{X}$ in obese black versus white adolescents: Race differential in diabetogenic and atherogenic risk factors. J Clin Endocrinol Metab 88:2534-2540

20. Danadian K, Balasekaran G, Lewy V, Meza MP, Robertson R, Arslanian SA 1999 Insulin sensitivity in African-American children with and without family history of type 2 diabetes. Diabetes Care 22:1325-1329

21. Kvist H, Chowdhury B, Grangard U, Tylen U, Sjostrom L 1988 Total and visceral adipose-tissue volumes derived from measurements with computed tomography in adult men and women: predictive equations. Am J Clin Nutr 48:1351-1361

22. Aaron DJ, Kriska AM, Dearwater SR, Anderson RL, Olsen TL, Cauley JA, Laporte RE 1993 The epidemiology of leisure physical activity in an adolescent population. Med Sci Sports Exerc 25:847-853

23. Aaron DJ, Kriska AM, Dearwater SR, Cauley JA, Metz KF, LaPorte RE 1995 Reproducibility and validity of an epidemiologic questionnaire to assess past year physical activity in adolescents. Am J Epidemiol 142:191-201

24. Cumming GR, Everatt D, Hastman L 1978 Bruce treadmill test in children: normal values in a clinic population. Am J Cardiol 41:69-75

25. Gidding SS, Nehgme R, Heise C, Muscar C, Linton A, Hassink S 2004 Severe obesity associated with cardiovascular deconditioning, high prevalence of cardiovascular risk factors, diabetes mellitus/hyperinsulinemia, and respiratory compromise. J Pediatr 144:766-769

26. Garn SM, Smith NJ, Clark DC 1975 Lifelong differences in hemoglobin levels between Blacks and Whites. JAMA 67:91-96 
27. Dallman PR, Barr GD, Allen CM, Shinefield HR 1978 Hemoglobin concentration in white, black, and Oriental children: is there a need for separate criteria in screening for anemia? Am J Clin Nutr 31:377-380.

28. McArdle WD, Katch FI, Katch VI 2001 Exercise Physiology: Exercise, Nutrition an Human Performance. Lippincott Williams \& Wilkins, Baltimore, pp 275-284

29. Rowland TW 2005 Children's Exercise Physiology. Human Kinetics, Champaign, pp 90-112

30. Hunter GR, Weinsier RL, McCarthy JP, Larson-Meyer DE, Newcomer BR 2001 Hemoglobin, muscle oxidative capacity and $\mathrm{VO}_{2 \max }$ in African-American and Caucasian women. Med Sci Sports Exerc 33:1739-1743

31. Stone HO, Thompson HK Jr., Schmidt-Nielsen K 1968 Influence of erythrocytes on blood viscosity. Am J Physiol 214:913-918

32. Schneider RG, Hightower B, Hosty TS, Ryder H, Tomlin G, Atkins R, Brimhall B Jones RT 1976 Abnormal hemoglobins in a quarter million people. Blood. 48:629637

33. Dallman PR, Siimes MA 1979 Percentile curves for hemoglobin and red cell volume in infancy and childhood. J Pediatr 94:26-31
34. Krahenbuhl GS, Skinner JS, Kohrt WM 1985 Developmental aspects of maximal aerobic power in children. Exerc Sport Sci Rev 13:503-538

35. Rowlands AV, Eston RG, Ingledew DK 1999 Relationship between activity levels, aerobic fitness, and body fat in 8- to 10-yr-old children. J Appl Physiol 86:1428-1435

36. Dietz WH, Gortmaker SL 2001 Preventing obesity in children and adolescents. Annu Rev Public Health 22:337-353

37. Caspersen CJ, Nixon PA, DuRant RH 1998 Physical activity epidemiology applied to children and adolescents. Exerc Sports Sci Rev 26:341-403

38. Dipitero L, Caspersen CJ 1991 National estimates of physical activity among white and black Americans. Med Sci Sports Exerc 23:S105

39. Bouchard C, Malina RM 1983 Genetics of physiologic fitness and motor performance. In: Terjung RL (ed) Exercise and Sports Sciences Reviews, Vol. 2. Franklin Institute, Philadelphia, pp 306-329.

40. Troiano RP, Flegal KM 1999 Overweight prevalence among youth in the United States: why so many different numbers? Int J Obes Relat Metab Disord 23:S22 S27 